\title{
Functional Properties of Apple Pomace Powder
}

\author{
Taru Negi* and Devina Vaidya \\ Department of Food Science and Technology, Dr. YS Parmar University of Horticulture and \\ Forestry, Nauni, Solan (HP) \\ *Corresponding author
}

\section{A B S T R A C T}

\begin{tabular}{|l|}
\hline Ke y w o r d s \\
$\begin{array}{l}\text { Apple pomace } \\
\text { powder, }\end{array}$ \\
$\begin{array}{l}\text { Hypoglycemic, } \alpha- \\
\text { amylase, GDRI, } \\
\text { GAC }\end{array}$ \\
\hline Article Info \\
\hline $\begin{array}{l}\text { Accepted: } \\
\text { 07 February } 2019 \\
\text { Available Online: } \\
\text { 10 March } 2019\end{array}$ \\
\hline
\end{tabular}

\section{Introduction}

Apple pomace, main by-product of apple juice industry contains $66.40-78.20$ per cent (wb) moisture and 9.50-22.00 per cent carbohydrates (Sun et al., 2007). It can be considered as a raw material for extraction of dietary fiber, since it contains $78.20-89.80$ per cent total dietary fiber content (Elleuch et al., 2011). Dietary fiber is the remnants of the edible part of plants and analogous carbohydrates that are resistant to digestion and absorption in the human small intestine with complete or partial fermentation in the
Apple pomace powder was analyzed for its functional properties which showed water holding capacity and fat absorption capacity of $3.39 \mathrm{~g} / \mathrm{g}$ and $0.97 \mathrm{ml} / \mathrm{g}$, respectively. Foam of apple pomace powder was not stable. Hypoglycemic potential of dietary fibers in managing diabetes is very well documented. In present study, the effect of apple pomace powder on $\alpha$-amylase, glucose diffusion and glucose adsorption were studied by using in vitro studies. The mechanism by which dietary fiber of apple pomace powder could exerts hypoglycemic effect includes inhibiting amylase activity, glucose adsorption capacity and glucose diffusion retardation index. $\alpha$ - amylase inhibition ration in apple pomace powder was 80 per cent. Glucose diffusion retardation index (GDRI) was maximum at 30 mile found decreased after 30 minutes. Glucose adsorption capacity (GAC) of apple pomace powder increased gradually with increase of glucose concentration. All of these mechanisms contribute towards the rate of reduction of glucose adsorption in the intestine, as a result, decrease the postprandial serum glucose concentration. 
prevalence of several diseases (Singh and Singh, 2015). It improves serum lipid concentration, lowers blood pressure, improves blood glucose control in diabetes, promote regularity, aids in weight loss and appears to improve immune function (Anderson et al., 2009). In this study, we analyzed the hypoglycemic potential of apple pomace powder and determined the effect of apple pomace powder on glucose adsorption in vitro.

\section{Materials and Methods}

\section{Material}

Fresh apple pomace was procured from Himachal Pradesh Horticultural Produce Marketing and Processing Corporation Ltd (HPMC) Fruit Processing Plant, located at Parwanoo, Distt. Solan (HP). The pomace was dried in the cabinet drier at $50 \pm 2^{\circ} \mathrm{C}$ for $24 \mathrm{~h}$. Dried pomace was then ground in Willey grinder and passed through sieve of 30 mesh $(500 \mu \mathrm{m})$. Apple pomace powder obtained after grinding used for further analysis.

\section{Methods}

\section{Bulk density (g/cc)}

A $50 \mathrm{~mL}$ graduated cylinder was filled with 20 $\mathrm{g}$ of sample followed by gentle tapping of the cylinder. The volume sample was read directly and results expressed as g/cc (Rana et al., 2015).

\section{Water hydration capacity (WHC)}

Weighed quantity (5 g) of sample was transferred to a centrifuge tube $(50 \mathrm{~mL})$ and weighed the tube with sample. Then distilled water was added in unmeasured increments till the pasty consistency was achieved. It was followed by centrifugation at $4000 \mathrm{rpm}$ for 10 min. Supernatant if any discarded and the tube was weighed again (Grover et al., 2003).
Water hydration capacity was measured as $\mathrm{mL}$ of water absorbed by per $\mathrm{g}$ of material.

WHC
solid $)$$\quad$ g water/g $=\frac{\begin{array}{c}\text { Final weight }- \text { Initial } \\ \text { weight }\end{array}}{\text { Initial weight }}$

\section{Fat binding capacity (FBC)}

Weighed quantity of sample $(0.5 \mathrm{~g})$ was thoroughly mixed $3 \mathrm{~g}$ of soya oil in centrifuge tube $(15 \mathrm{~mL})$ and allowed to stand for $30 \mathrm{~min}$ followed by centrifugation at $1610 \mathrm{rpm}$ for 25 min. Then the volume of free oil was measured (Grover et al., 2003). Fat absorption was expressed as the amount of oil bound by $100 \mathrm{~g}$ of sample.

$\mathrm{FBC}$
solid $)$$\quad\left(\mathrm{g} \quad\right.$ oil $\quad / \mathrm{g}=\frac{\begin{array}{c}\text { Final weight }- \text { Initial } \\ \text { weight }\end{array}}{\text { Initial weight }}$

\section{Swelling power and Solubility index}

Sample $(1 \mathrm{~g})$ was taken in a test tube. $50 \mathrm{ml}$ of distilled water was added and mixed properly. The slurry was heated at $85^{\circ} \mathrm{C}$ for $30 \mathrm{~min}$ in water bath. After cooling, the sample was centrifuged at 2,000 rpm for $15 \mathrm{~min}$. The supernatant was collected in a dish and $5 \mathrm{~mL}$ of it was poured on tarred evaporating dish (B1) and was dried at $100^{\circ} \mathrm{C}$ for $4 \mathrm{~h}$ and weighed again (A2) (Younis and Ahmad, 2015). Then, the weight of sediment was taken as (W2).

Swelling power $(\%)=\mathrm{W} 2-\mathrm{W} 1 /$ Weight of sample $\times 100$

Solubility index $(\%)=\mathrm{A} 2-\mathrm{B} 1 /$ Weight of sample $\times 100$

\section{Foam Capacity (FC)}

One gram of sample was mixed with $100 \mathrm{~mL}$ of distilled water and the suspension was 
homogenised vigorously for $5 \mathrm{~min}$ by using a homogeniser. The homogenised suspension was immediately transferred to a $250 \mathrm{~mL}$ graduated cylinder and the foam volume was measured (Gannasin et al., 2012)

$$
\begin{aligned}
& \mathrm{FC}= \\
& (\%) \\
& \begin{array}{l}
\text { Volume before homogenisation }) \\
\text { (Volume before homogenisation) } \\
\mathrm{mL}
\end{array}
\end{aligned}
$$

\section{Foam Stability (FS)}

Foam stability (FS) was measured by measuring the foam volume after allowing the foam to stand for $1 \mathrm{hr}$ (Ahmad et al., 2016)

FS $(\%)=\frac{\text { Foam volume after } 1 \mathrm{~h}}{\text { Initial foam volume }} \times 100$

\section{Emulsion Activity (EA)}

A known quantity ( $7 \mathrm{~g}$ ) of sample preparation was suspended in $100 \mathrm{~mL}$ distilled water and added $100 \mathrm{~mL}$ of oil followed by emulsification of mixture in a homogenizer at $10,000 \mathrm{rpm}$ for $1 \mathrm{~min}$. The emulsion obtained was centrifuged at $1300 \mathrm{rpm}$ for $5 \mathrm{~min}$ (Grover et al., 2003). The emulsion activity was calculated using the following equation:

$$
\text { EA }(\%)=\frac{\text { Height of emulsion layer }}{\text { Total emulsion layer }} \times 100
$$

\section{Emulsion Stability (ES)}

A known quantity $(7 \mathrm{~g})$ of sample preparation was suspended in $100 \mathrm{~mL}$ distilled water and added $100 \mathrm{~mL}$ of oil followed by emulsification of mixture in a homogenizer at $10,000 \mathrm{rpm}$ for $1 \mathrm{~min}$.

Heat emulsion at $80^{\circ} \mathrm{C}$ for $30 \mathrm{~min}$ and centrifuge at $1300 \mathrm{rpm}$ for $5 \mathrm{~min}$ (Grover et al., 2003). The emulsion stability was calculated using the following equation:
ES $(\%)=\frac{\begin{array}{l}\text { Height of remaining } \\ \text { emulsion }\end{array}}{\text { Total height of emulsion }} \times 100$

$\alpha$-amylase activity inhibition ration ( $\alpha$ AAIR)

$1 \mathrm{~g}$ apple pomace was mixed with $25 \mathrm{ml}$ of soluble starch $(4 \mathrm{~g} / 100 \mathrm{ml}, \mathrm{pH} 6.5)$ and $0.1 \mathrm{~g}$ of $\alpha$-amylase. The mixture was dialyzed against distilled water at $37^{\circ} \mathrm{C}$ in a shaking water bath (Zheng and $\mathrm{Li}, 2018$ ). The dialysate glucose content was determined after $60 \mathrm{~min}$. A control test was carried out without sample, and $\alpha$-AAIR was calculated by the following equation:

$\alpha-\operatorname{AAIR}(\%)=(\mathrm{Ac}-\mathrm{As}) / \operatorname{Ac} \times 100$

where Ac is the absorbance of the control and As is the absorbance of sample.

\section{Glucose diffusion retardation index (GDRI)}

Sample $(0.25 \mathrm{~g})$ was mixed with $12.5 \mathrm{~mL}$ of glucose solution $\left(50 \mathrm{mmol} \mathrm{L}^{-1}\right)$ in a dialysis membrane with a cut-off molecular weight of 12,000. The mixture solution was dialyzed against $100 \mathrm{~mL}$ of distilled water. After 30, 60 , and $120 \mathrm{~min}$, the glucose content in the dialysate was measured using the glucose assay kit to determine the glucose diffusion rate. A control test was carried out (Younis and Ahmad, 2015). It is calculated as below:-

$$
\begin{aligned}
& \text { GDRI }(\%) \quad=\quad 100 \quad- \\
& {\left[\left(\frac{\text { Total glucose diffused from fiber sample }}{\text { Total glucose diffused from control sample }}\right) \times 100\right]}
\end{aligned}
$$

\section{Glucose adsorption capacity (GAC)}

Sample (1g) was mixed with $100 \mathrm{~mL}$ of different glucose concentrations $(50,100,200$ mmol L ${ }^{-1}$ ) and incubated at $37^{\circ} \mathrm{C}$ for $6 \mathrm{~h}$. The sample was centrifuged at $4000 \mathrm{rpm}$ for 20 min after glucose adsorption reached equilibrium. The amount of glucose retained 
by sample was determined by measuring the supernatant glucose content using a glucose assay kit ( $\mathrm{Ma}$ and $\mathrm{Mu}, 2016$ ). Glucose adsorption capacity was calculated using the following formula:-

GAC $(\mathrm{mmol} / \mathrm{g})=\frac{\mathrm{G} 1-\mathrm{G} 6}{\text { Weight of the sample }} \times$ Volume of solution

Where, $\mathrm{G} 1=$ Glucose concentration of original solution

G6 = Glucose concentration after $6 \mathrm{~h}$.

\section{Results and Discussion}

The data presented in table 1 shows the bulk density of apple pomace powder i.e. $0.48 \mathrm{~g} / \mathrm{cc}$. Water holding capacity (WHC) and fat absorption capacity (FAC) were observed 3.39 and $0.97 \mathrm{ml} / \mathrm{g}$ respectively, whereas swelling power, solubility index, foaming capacity, emulsion activity, emulsion stability was 1265.20, 4.00, 2.00, 46.87 and 31.25 per cent respectively. Similar results were observed by Younis and Ahmad (2015). Foam stability was recorded zero due to negligible foam formation in apple pomace powder. The values recorded by Grover et al., (2003) for foam activity, foam stability, emulsion activity and emulsion stability were 7.0 per cent, 0 per cent, 39.6 per cent and 38.4 per cent in apple pomace powder.

$\alpha$-amylase inhibition ration was found 80 per cent in apple pomace powder (Table 1). It indicate that apple pomace powder was most effective inhibitor of amylase activity. The retardation of $\alpha$-amylase activity might be due to possible reasons, such as capsulation of starch and enzyme by fibers, reduced accessibility of the enzyme to starch, the presence of inhibitors on fibers and the direct adsorption of enzyme on fibers leading to the decrease in amylase activity. The ability of apple pomace powder in lowering the activity of $\alpha$-amylase might help in postponing the release of glucose from starch, delaying the rate of glucose absorption, and therefore controlling the concentration of postprandial serum glucose.

The effect of apple pomace powder on glucose diffusion is presented in Figure 1. Dialysis membrane was monitored after 30, 60 and 120 min to check the movement of glucose across the membrane. In control, the glucose content in the dialysate was measured 2500, 1000 and $500 \mathrm{mg} / \mathrm{l}$ whereas in case of apple pomace powder the glucose content was found 7000 , 4000 and $2000 \mathrm{mg} / \mathrm{l}$. Glucose Diffusion Retardation Index (GDRI) is a useful in vitro index to predict the effect of a fiber on the delay in glucose absorption in the gastrointestinal tract (Lopez et al., 1996). In the present study, it was observed that GDRI (Fig. 2) was maximum at $30 \mathrm{~min}(69.23 \%)$ and decreased on extension of dialysis period. The similar trend of GDRI was recorded by Ahmed et al., (2011) in wheat bran, acarbose, oats, and psyllium husk. It was reported that apple pomace powder demonstrated significant inhibitory effect on movement of glucose into external solution across dialysis membrane compared to control. The reason may be the physical obstacle presented by fiber particle towards glucose molecules and the entrapment of glucose within the network formed by fibers (Ahmed et al., 2011). This property of apple pomace powder might be useful for lowering the glycemic index by its incorporation in foods with high glycemic index.

Glucose adsorption capacity of apple pomace powder is presented in Figure 3. The fiber samples at different glucose concentrations were $(50,100$ and $200 \mathrm{mmol} / \mathrm{l})$ found to bind glucose at different levels (3.88, 8.61 and $18.33 \mathrm{mmol} / \mathrm{g}$ ) respectively. The adsorption capacity of the apple pomace powder was directly proportional to the molar concentration of glucose. 
Table.1 Functional properties of apple pomace powder

\begin{tabular}{|c|c|}
\hline Functional Properties & Treatments $($ Mean $\pm \mathrm{SE})$ \\
\hline Bulk density (BD) (g/cc) & $0.48 \pm 0.01$ \\
\hline Water holding capacity (WHC) (g/g) & $3.39 \pm 0.01$ \\
\hline Fat absorption capacity (FAC) $(\mathrm{ml} / \mathrm{g})$ & $0.97 \pm 0.02$ \\
\hline Swelling Power (SP) (\%) & $1265.20 \pm 0.01$ \\
\hline Solubility index (SI) (\%) & $4.00 \pm 0.57$ \\
\hline Foam capacity $(\mathrm{FC})(\%)$ & $2.00 \pm 0.57$ \\
\hline Foam stability (FS) (\%) & NS \\
\hline Emulsion activity (EA) (\%) & $46.87 \pm 0.01$ \\
\hline Emulsion stability (ES) (\%) & $31.25 \pm 0.01$ \\
\hline$\alpha$ - amylase inhibition ration $(\alpha-\mathrm{AAIR})$ & $80 \pm 0.02$ \\
\hline
\end{tabular}

Fig.1 Effect of apple pomace powder on glucose diffusion

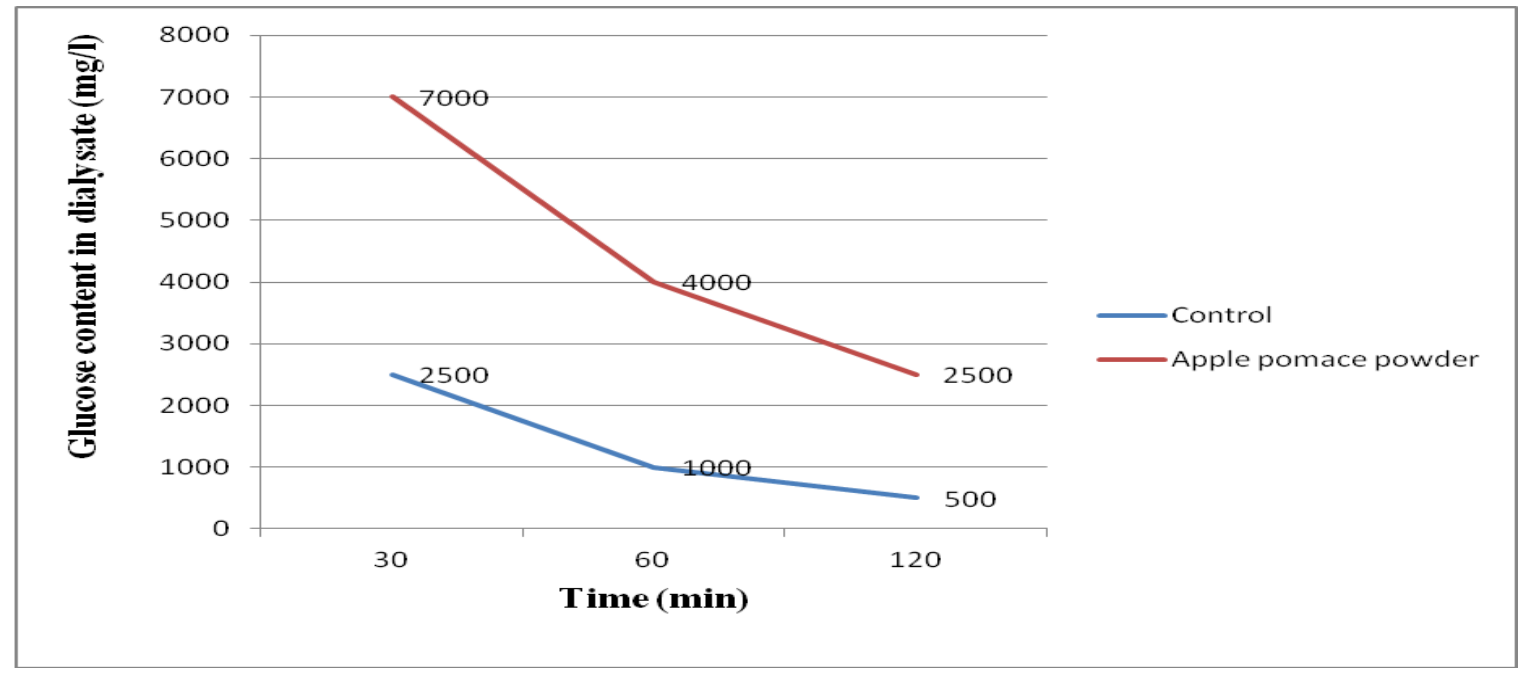

Fig.2 Glucose dialysis retardation index of apple pomace powder

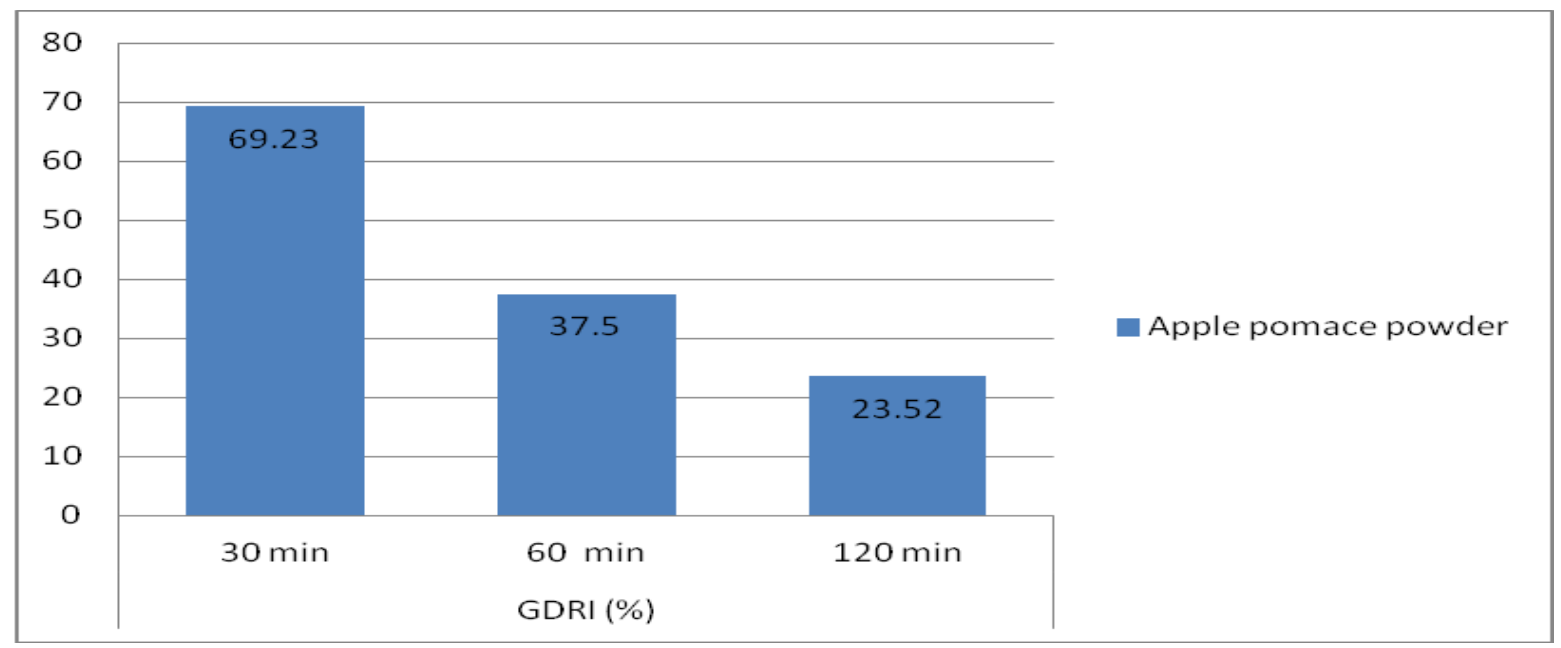


Fig.3 Glucose adsorption capacity of apple pomace powder

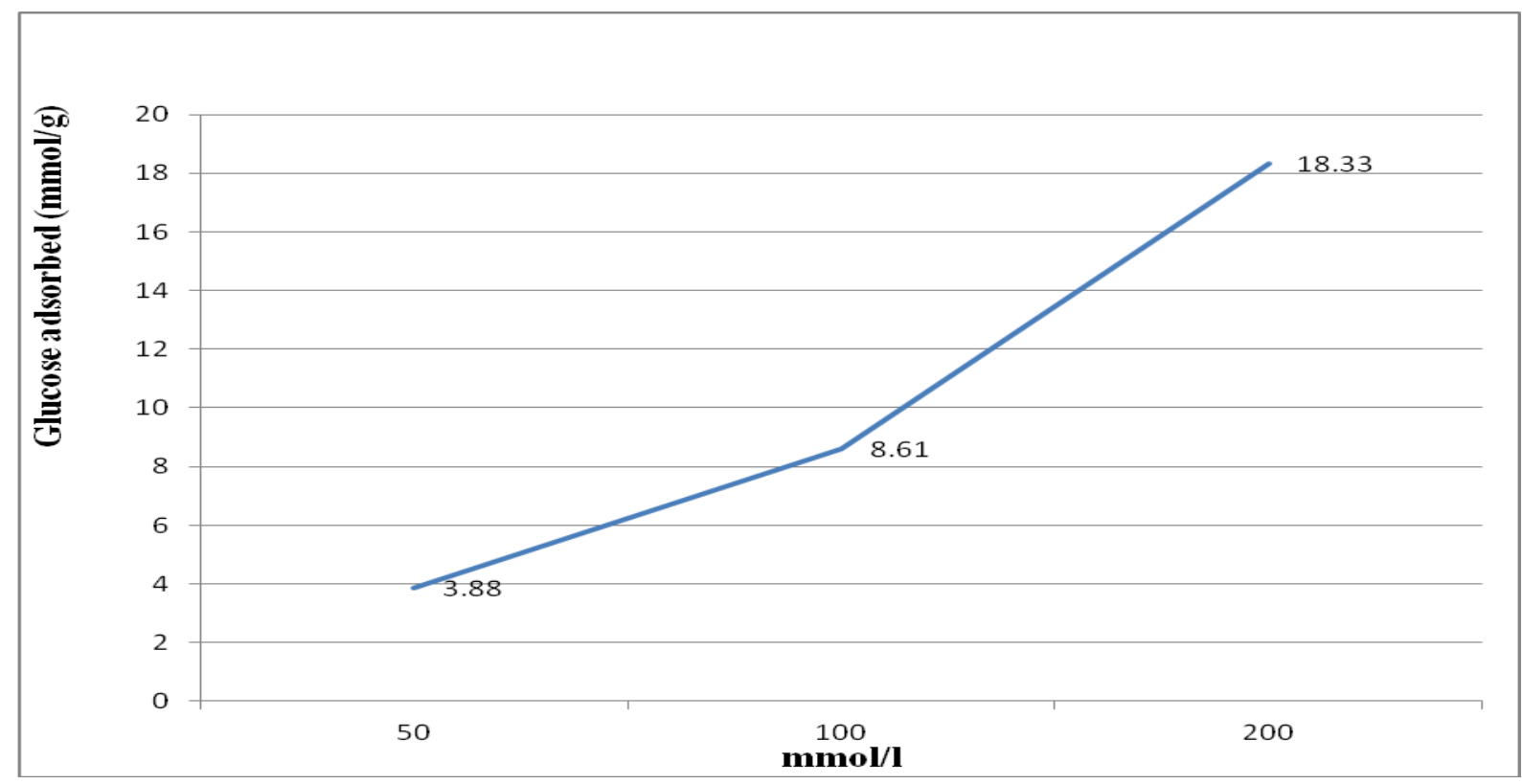

The result of this in vitro study indicates that the glucose adsorption capacity of fiber increased gradually when the glucose concentration increased. The sample could bind glucose even at lower concentration thereby reducing the amount of glucose available for transport across the intestinal lumen. This could help in lowering postprandial hyperglycemia. Similar trend was reported by $\mathrm{Ma}$ and $\mathrm{Mu}$ (2016) in dietary fiber of deoiled cumin.

From this research, it has been concluded that apple pomace powder has various versatile functional properties like water holding capacity, fat absorption capacity, swelling power, foam capacity and stability, glucose diffusion retardation index etc. This study demonstrated that apple pomace powder could effectively adsorb glucose, retard the glucose diffusion and inhibit the $\alpha$-amylase activity which results in lowering the postprandial hyperglycemia. $\alpha$-amylase inhibition ration was found 80 per cent in apple pomace powder. GDRI was maximum at $30 \mathrm{~min}(69.23 \%)$ thereafter the GDRI decreased significantly. It was interesting to note that the adsorption of glucose by apple pomace powder increased with increase in glucose concentration. All of these mechanisms helps to lower the rate of glucose adsorption and as a result, decrease the postprandial serum glucose concentration. However, further in vivo studies are needed to analyze these observation.

\section{References}

Ahmad, M., Wani1, T.A., Wani1, S.M., Masoodi, F.A., and Gani, A. 2016. Incorporation of carrot pomace powder in wheat flour: effect on flour, dough and cookie characteristics. Journal of Food Science and Technology DOI 10.1007/s13197-016-2345-2.

Ahmed, F., S, Sairam., and Urooj, A. 2011. In vitro hypoglycemic effects of selected dietary fiber sources. Journal of Food Science and Technology. 48: 285-289.

Anderson, J.W., Richard, P.B., Davis, R.H., Ferreri, S., Knudtson, M., Koraym, A., Waters, V., and Williams, C.L. 2009. Health benefits of dietary fiber. Nutrition Reviews. 67: 188-205.

Elleuch, M., Bedigian, D., Roiseux, O., Besbes, S., Blecker, C., and Attia, H. 2011. Dietary 
fibre and fibre-rich by-products of food processing: Characterisation, technological functionality and commercial applications: a review. Food Chemistry. 124: 411-421.

Forsythe, W.A., Chenoweth, W., and Bennink, M.R. 1976. The effect of various dietary fibres on serum cholesterol and laxation in the rat. Journal of Nutrition. 106: 26-32.

Gannasin, S.P., Ramakrishnan, Y., Adzahan, N.M., and Muhammad, K. 2012. Functional and Preliminary Characterisation of Hydrocolloid from Tamarillo (Solanum betaceum Cav.) Puree. Molecules 17: 68696885.

Grover, S.S., Chauhan, G.S., and Masoodi, F.A. 2003. Effect of particle size on surface properties of apple pomace. International Journal of Food Properties 6:1-7.

ICMR. 2009. Nutrient Requirements and Recommended Dietary Allowances for Indians. Indian Council of Medical Research, Hyderabad. 143p.

Lopez, G., Ros, G., Rincon, F., Periago, M.J., Martinez, M.C., and Ortuno, J. 1996. Relationship between physical and hydration properties of soluble and insoluble fiber of artichoke. Journal of Agricultural and Food Chemistry. 44: 27732778.

Ma, M., and Mu, T. 2016. Effects of extraction methods and particle size distribution on the structural, physicochemical, and functional properties of dietary fiber from deoiled cumin. Food Chemistry. pp. 237246.

Mckee, L.H., and Latner, T.A. 2000. Underutilized sources of dietary fiber: a review. Plant Foods for Human Nutrition. 55:285-304

Ogino, Y., Osada, K., Nakamura, S., Ohta, Y.,
Kanda, T., and Sugano, M. 2007. Absorption of dietary cholesterol oxidation products and their downstream metabolic effects are reduced by dietary apple polyphenols. Lipids. 42:151-161.

Osada, K., Suzuki, T., Kawakami, Y., Senda, M., Kasai, A., Sami, M., Ohta, Y., Kana, T., and Ikeda, M. 2006. Dose dependent hypocholesterolemic actions of dietary apple polyphenol in rats fed cholesterol. Lipids. 41:133-139.

Rana, S., Gupta, S., Rana, A., and Bhushan, S. 2015. Functional Properties, Phenolic constituents and Antioxidant Potential of Industrial Apple Pomace for Utilization as Active Food Ingredient. Food Science and Human Wellness http://dx.doi.org/10.1016/ j.fshw.2015.10.001

Singh, A., and Singh, S.N. 2015. Dietary fiber content of Indian diets. Asian Journal of Pharmaceutical and Clinical Research. 8:58-61.

Sun, J., Hu, X., Zhao, G., Wu, J., Wang, Z., Chen, F., and Liao, X. 2007. Characteristics of thin layer infrared drying of apple pomace with and without hot air pre-drying. Food Science and Technology International. 13:91-97.

Younis, K., and Ahmad, S. 2015. Waste utilization of apple pomace as a source of functional ingredient in buffalo meat sausage. Cogent Food and Agriculture. 1:110.

Zheng, Y., and Li, Y. 2018. Physico chemical and functional properties of coconut (Cocos nucifera $\mathrm{L}$ ) cake dietary fibres: Effect of cellulose hydrolysis, acid treatment and particle size distribution. Food Chemistry. 135-142.

\section{How to cite this article:}

Taru Negi and Devina Vaidya. 2019. Functional Properties of Apple Pomace Powder. Int.J.Curr.Microbiol.App.Sci. 8(03): 589-595. doi: https://doi.org/10.20546/ijcmas.2019.803.072 